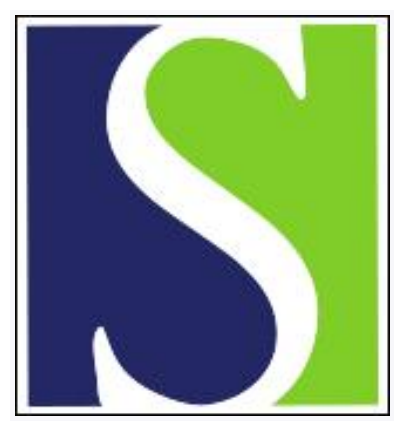

Scand J Work Environ Health 1990;16(5):323-328

https://doi.org/10.5271/sjweh.1777

Issue date: 00 Oct 1990

Spontaneous abortion among women using video display terminals.

by Nielsen CV, Brandt LP

Affiliation: Institute of Social Medicine, University of Aarhus, Denmark.

This article in PubMed: www.ncbi.nlm.nih.gov/pubmed/2255872

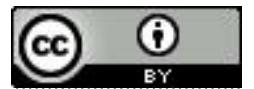




\title{
Spontaneous abortion among women using video display terminals
}

\author{
by Claus V Nielsen, MD, ${ }^{1,2}$ Lars PA Brandt, $M^{1,2}$
}

\begin{abstract}
NIELSEN CV, BRANDT LPA. Spontaneous abortion among women using video display terminals. Scand $J$ Work Environ Health 1990;16:323-8. This case-base study with a source population of 214108 commercial and clerical workers investigated the risk of adverse pregnancy outcome among women working with a video display terminal (VDT) in Denmark. A subpopulation was obtained by register linkage between a trade union membership file, the Medical Birth Register, and the National Register of In-Patients. In two years 24352 pregnancy outcomes were registered, 2248 spontaneous abortions were recorded, and a base sample of 2252 pregnancies was randomly selected. Data on VDT use, job stress, ergonomic factors, and life-style factors were collected with questionnaires sent to 6212 women and 426 employers. There was no increased risk of medically verified spontaneous abortion among women with VDT use. The relative risk for women exposed to any degree of use was 0.94 (95\% confidence interval $0.77-1.14)$. Ergonomic work load and job stress were not confounders.
\end{abstract}

Key terms: case-base study, recall bias, reproductive failures, selection bias, work during pregnancy.

Clusters of adverse pregnancy outcomes have been reported among women using a video display terminal (VDT), and, although such clusters could occur by chance (1), there has been increased concern about the potential reproductive hazards of VDT use. The main concern has, thus far, been the exposure to extremely low-frequency electromagnetic fields. Studies of animals and human cells provide, however, only limited support for the presumption that exposure to lowfrequency electromagnetic fields results in reproductive failure (1).

Four large-scale epidemiologic studies investigating the risk of spontaneous abortion among VDT users have been published $(2-5)$. Ericson \& Källén $(2,3)$ found a very weak association between increased VDT use and abortion. Furthermore, they found a weaker overall association between VDT use at any time and spontaneous abortion. None of their findings were statistically significant at the $5 \%$ level. McDonald et al (4) found a statistically significant association between VDT use for $1-29 \mathrm{~h}$ /week and the occurrence of spontaneous abortion. Goldhaber et al (5) found a statistically significant association between spontaneous abortion and VDT exposure for more than $20 \mathrm{~h} /$ week.

The present study of medically verified spontaneous abortions was part of an investigation initiated by the Union of Commercial and Clerical Employees in Denmark. Its purpose was to estimate the risk of ad-

1 Institute of Social Medicine, University of Aarhus, Aarhus, Denmark.

2 Department of Occupational Medicine, Municipal Hospital of Aarhus, Aarhus, Denmark.

Reprint requests to: Dr CV Nielsen, Institute of Social Medicine, University of Aarhus, Hoegh-Guldbergsgade 8, DK-8000 Aarhus C, Denmark. verse pregnancy outcome for VDT-using members of the Union. The results with respect to the association between congenital malformations and VDT use have been presented elsewhere (6).

\section{Subjects and methods}

\section{Selection of subjects and information}

The investigation was designed as a case-base study (7). The source population was defined as all women in Denmark between the ages of 15 and 44 years who had been a member of the Union of Commercial and Clerical Employees for at least one month from 1982 to 1985. A total of 214108 women fulfilled these criteria. Approximately $80 \%$ of all Danish women employed in commercial or clerical jobs (ie, various job categories in retail, wholesale, production, and service) belong to this trade union. In fact, the source population in the present study comprises about one-fifth of all gainfully employed Danish women between the ages of 15 and 44 years.

By means of the women's personal identification numbers, register linkage was achieved between the trade union file and two nationwide health registers, namely, the Medical Birth Register and the National Register of In-Patients. The Medical Birth Register provides information on pregnancy outcome and all recorded diagnoses for more than $95 \%$ of all births in Denmark, and it is based on both the midwives' and physicians' reports. The National Register of In-Patients provides information on all admissions to any Danish hospital, and it includes all diagnoses made by physicians in hospitals.

The population experience was defined as all pregnancy outcomes in the source population, with the ex- 
ception of twins, triplets, and induced abortions. The study was restricted to a two-year period from 1 July 1983 to 30 June 1985 for spontaneous abortions and from 1 January 1984 to 31 December 1985 for births.

Eight case groups were defined, covering various adverse pregnancy outcomes, that is, spontaneous abortions, light for dates, preterm deliveries, low birthweights, congenital malformations, stillbirths, perinatal deaths, and infant deaths. The base sample (reference group) was a $9.2 \%$ random sample $(\mathrm{N}=2252)$ of the source population. The base sample included almost the same number of cases as the largest case group (ie, spontaneous abortions, $\mathrm{N}=2248$ ). Table 1

Table 1. Distribution of pregnancy outcomes in the source population of 214108 women and a base sample of the source population observed over a period of two years. The data on the source population are given for the purpose of comparison.

\begin{tabular}{|c|c|c|c|c|}
\hline \multirow[t]{2}{*}{ Pregnancy outcome } & \multicolumn{2}{|c|}{$\begin{array}{c}\text { Source } \\
\text { population } \\
\text { experience }\end{array}$} & \multicolumn{2}{|c|}{$\begin{array}{c}\text { Base } \\
\text { samplea }\end{array}$} \\
\hline & $\mathrm{N}$ & $\%$ & $\mathrm{~N}$ & $\%$ \\
\hline Delivery (singleton) & 21554 & 88.5 & 1976 & 87.7 \\
\hline Spontaneous abortion & $2248^{b}$ & 9.2 & 225 & 10.0 \\
\hline Congenital malformation & $661^{\mathrm{b}}$ & 2.7 & 71 & 3.2 \\
\hline Light for dates ${ }^{c}$ & $988^{b}$ & 4.1 & 94 & 4.2 \\
\hline Low birthweightd & $587^{\circ}$ & 2.4 & 55 & 2.4 \\
\hline Preterm birthe & $593^{\mathrm{b}}$ & 2.4 & 50 & 2.2 \\
\hline $\begin{array}{l}\text { Stillbirth and death } \\
\text { in the first year of life }\end{array}$ & $209^{b}$ & 0.1 & 17 & 0.1 \\
\hline Extrauterine pregnancy & 332 & 1.4 & 38 & 1.7 \\
\hline Unspecified abortion & 228 & 0.1 & 21 & 1.0 \\
\hline
\end{tabular}

Total number of pregnancy

outcomes diagnosed once

or more

24362

2252

a The base sample is a $9.2 \%$ random sample of the source population. A pregnancy outcome in the base sample can also appear in one or more of the case groups.

b These groups were the case groups in the investigation.

c Birthweight in the lowest fifth percentile for gestational age of each c Birthir.

$<2500$

e Before week 37 of gestation. shows the number and distribution of pregnancies in the source population, in the case groups, and in the base sample. It can be seen that some cases were included in the base sample.

Table 2 shows the distribution of one diagnosis or more of the total number of pregnancies in the base sample and the case groups.

The employers of women using a VDT at any time during their pregnancy were identified by register linkage of the case and base sample groups and the Labour Market Supplementary Pension Fund.

\section{Recording of spontaneous abortions}

Most women who have experienced a recognized spontaneous abortion are referred to a hospital for diagnostic confirmation and treatment. The diagnosis is made by the physician in charge and is recorded in the National Register of In-Patients as prescribed in the eighth revision of the International Classification of Diseases (ICD-8). In this study the ICD-8 codes 642, 634.61 , and 645.1 were used for the identification and selection of spontaneous abortions.

Since data on the week of gestation in which the spontaneous abortion occurred were not available, the time of conception was estimated to be three months prior to the spontaneous abortion on the average. All cases in the source population were included; 2248 spontaneous abortions were identified.

\section{Assessment of exposure}

The prevalence of VDT use varies over time. In order to make a more precise comparison of the pregnancies ending in spontaneous abortion with successful pregnancies, a special matching technique was used. This technique takes the time of estimated conception, rather than the termination of pregnancy, as the starting point when measuring the prevalence of VDT use.

Table 2. Distribution of one diagnosis or more of the pregnancy outcomes among 214108 Danish women observed over a period of two years in defined case groups (total $\mathrm{N}=4660$ ) and a $9.2 \%$ random sample (base sample) $(\mathrm{N}=2252)$ of the source population.

\begin{tabular}{|c|c|c|c|c|c|c|c|c|c|c|c|c|c|}
\hline \multirow{2}{*}{$\begin{array}{l}\text { Pregnancy } \\
\text { outcome }\end{array}$} & \multirow{2}{*}{ 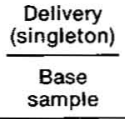 } & \multicolumn{2}{|c|}{$\begin{array}{c}\text { Spontaneous } \\
\text { abortion }\end{array}$} & \multicolumn{2}{|c|}{$\begin{array}{c}\text { Congenital } \\
\text { malformation }\end{array}$} & \multicolumn{2}{|c|}{$\begin{array}{l}\text { Stillbirth } \\
\text { or death }\end{array}$} & \multicolumn{2}{|c|}{$\begin{array}{l}\text { Light for } \\
\text { dates }\end{array}$} & \multicolumn{2}{|c|}{$\begin{array}{c}\text { Preterm } \\
\text { birth }\end{array}$} & \multicolumn{2}{|c|}{$\begin{array}{l}\text { Low } \\
\text { birthweight }\end{array}$} \\
\hline & & $\begin{array}{l}\text { Case } \\
\text { group }\end{array}$ & $\begin{array}{l}\text { Base } \\
\text { sample }\end{array}$ & $\begin{array}{l}\text { Case } \\
\text { group }\end{array}$ & $\begin{array}{l}\text { Base } \\
\text { sample }\end{array}$ & $\begin{array}{l}\text { Case } \\
\text { group }\end{array}$ & $\begin{array}{l}\text { Base } \\
\text { sample }\end{array}$ & $\begin{array}{l}\text { Case } \\
\text { group }\end{array}$ & $\begin{array}{c}\text { Base } \\
\text { sample }\end{array}$ & $\begin{array}{l}\text { Case } \\
\text { group }\end{array}$ & $\begin{array}{l}\text { Base } \\
\text { sample }\end{array}$ & $\begin{array}{l}\text { Case } \\
\text { group }\end{array}$ & $\begin{array}{c}\text { Base } \\
\text { sample }\end{array}$ \\
\hline $\begin{array}{l}\text { Delivery } \\
\text { (singleton) }\end{array}$ & 1968 & $\cdot$ & $\cdot$ & . & 71 & · & 17 & $\cdot$ & 94 & $\cdot$ & 50 & · & 55 \\
\hline $\begin{array}{l}\text { Spontaneous } \\
\text { abortion }\end{array}$ & · & 2248 & 225 & $\cdot$ & $\cdot$ & $\cdot$ & $\cdot$ & $\cdot$ & - & . & . & $\cdot$ & • \\
\hline $\begin{array}{l}\text { Congenital } \\
\text { malformation }\end{array}$ & 71 & $\cdot$ & . & 661 & 71 & 65 & 6 & 61 & 6 & 47 & 4 & 44 & 3 \\
\hline $\begin{array}{l}\text { Stillbirth or } \\
\text { death }^{\text {a }}\end{array}$ & 17 & $\cdot$ & . & 65 & 6 & 209 & 17 & 17 & 1 & 47 & 4 & 11 & 1 \\
\hline $\begin{array}{l}\text { Light for } \\
\text { dates }\end{array}$ & 94 & $\cdot$ & . & 61 & 6 & 17 & 1 & 988 & 94 & 20 & 1 & 357 & 37 \\
\hline Preterm birth & 50 & . & . & 66 & 4 & 47 & 4 & 20 & 1 & 593 & 50 & - & - \\
\hline Low birthweight & 55 & . & $\ddots$ & 44 & 3 & 11 & 1 & 357 & 37 & - & - & 587 & 55 \\
\hline
\end{tabular}

a Death $=$ death in the first year of life. 
Data on the week of gestation at the time of the spontaneous abortion were not available, and thus the time of conception was estimated to be three months prior to the spontaneous abortion. An estimate of the degree of exposure to a VDT was made for the followup period of two years.

In September 1987 a questionnaire with 72 questions was mailed to all women in the base sample and the case groups. The women were asked to give information on occupational status, job title, job stress, ergonomic work load, exposure to organic solvents, VDT use, and life-style factors (eg, alcohol consumption, smoking, and general state of health) for every pregnancy from 1983 to 1985 . One question concerned the number of hours of VDT work during pregnancy: "How many hours (on the average per week) did you work with a VDT during pregnancy?"

The response rate was $75.4 \%$ ( 1699 pregnancies) for the base sample and $61.0 \%$ (1371 pregnancies) for the case group of spontaneous abortions. A random sample of 215 was taken of the nonresponders of the base sample $(\mathrm{N}=945)$ and of the spontaneous abortion case group $(\mathrm{N}=645)$. In order to explore the possibility of selection bias, interviewers who did not know the outcome of the pregnancy interviewed the nonresponders who had a telephone $(84.8 \%$ ). Among these nonresponders $27.5 \%$ in the group of spontaneous abortions and $19.3 \%$ in the base sample still refused to answer the questionnaire.

Selective recall is a known potential problem in casereferent and case-base studies. To control for this problem, we questioned the employers of the pregnant women about the extent of VDT use. All the women who had used a VDT during their pregnancies were asked permission to contact their employer. A total of 185 women in the case group of spontaneous abortions and 284 women in the base sample gave their consent. By register linkage of the women's personal identification number and the Labour Market Supplementary Fund, the employers were identified. A questionnaire with six questions concerning VDT use was sent to a random sample of $63.9 \%$ of the employers in March 1988. A question concerning hours of VDT work corresponded to the question given to the women. The response rate was $93.6 \%$ and $88.5 \%$, respectively, for the group of spontaneous abortions and the base sample group.

\section{Analysis}

As the base sample was a random sample of the total source population, it was possible to obtain a direct estimate of the relative risk even if the rare disease assumption was not fulfilled. Control for bias induced by potential confounders was made. The classification of the potential confounding variables/covariates used are shown in table 3. A potential confounding variable was adjusted for if it was statistically significantly associated with spontaneous abortion at a $5 \%$ level.
The model used for the statistical analysis was the Mantel-Haenszel stratified analysis modified to casebase studies by Greenland (8).

In the base sample, $80.6 \%$ were employed. Of the employed, $33.5 \%$ worked with a VDT. The proportion of VDT users in the subgroup of clerical and administrative employees was $55.2 \%$. The subgroup of clerical and administrative female employees formed the basis for the rest of the analysis made in this study.

\section{Results}

The proportion of spontaneous abortions for women gainfully employed during pregnancy can be calculated for the base sample as the total number of spontaneous abortions divided by the sum of the total number of spontaneous abortions plus the total number of deliveries $[119 /(119+1224)]$, the resulting percentage being $8.9 \%$. The corresponding proportion of spontaneous abortions for the unemployed women in the base sample $[28 /(28+302)]$ equaled $8.5 \%$.

Table 4 shows that VDT use during pregnancy did not increase the frequency of spontaneous abortions. The relative rate ratio was 0.92 for VDT use at any

Table 3. The variables (potential confounders) used in the analysis.

\begin{tabular}{|c|c|}
\hline Covariables & Classification \\
\hline Maternal age & $15-29$ years, $\geq 30$ years. \\
\hline Previous pregnancies & 0,1 and $>1$ \\
\hline Previous deliveries & 0,1 and $>1$ \\
\hline Job-stress factors & $\begin{array}{l}\text { Two-level stress index based } \\
\text { on the responses to } 12 \text { ques- } \\
\text { tions on job stressors }\end{array}$ \\
\hline Ergonomic work load & $\begin{array}{l}\text { Heavy lifting (yes/no); sitting } \\
\text { more than } 1 \mathrm{~h} \text { at a time during } \\
\text { a workday (yes/no); standing } \\
\text { more than } 1 \mathrm{~h} \text { at a time during } \\
\text { a workday (yes/no); variation in } \\
\text { work position during a workday } \\
\text { (yes/no); standing, sitting, mov- } \\
\text { ing }(0-2 \mathrm{~h} / \mathrm{d}, 3-4 \mathrm{~h} / \mathrm{d}, 5-6 \mathrm{~h} / \mathrm{d} \\
\text { and } \geq 7 \mathrm{~h} / \mathrm{d}) \text {; treatment of cer- } \\
\text { vicobracial disorders during } \\
\text { pregnancy (yes/no) }\end{array}$ \\
\hline Organic solvents & $\begin{array}{l}\text { Daily exposure at work } \\
\text { (yesino) }\end{array}$ \\
\hline Smoking & $\begin{array}{l}0,1-10, \geq 11 \text { cigarettes } / \mathrm{d} \\
\text { during first trimester }\end{array}$ \\
\hline Alcohol & $\begin{array}{l}0,1-4, \geq 5 \text { drinks/week during } \\
\text { first trimester; more than } 10 \\
\text { drinks on certain occasions } \\
\text { during first trimester (yes/no) }\end{array}$ \\
\hline Medication & $\begin{array}{l}\text { Regular consumption of medi- } \\
\text { cine during first trimester } \\
\text { (yes/no) }\end{array}$ \\
\hline Infections & $\begin{array}{l}\text { Infections during first trimester } \\
\text { (yes/no) }\end{array}$ \\
\hline Chronic diseases & $\begin{array}{l}\text { One year before pregnancy, } \\
\text { diagnosed by physician } \\
\text { (yes/no) }\end{array}$ \\
\hline
\end{tabular}


Table 4. Risk ratios for medically verified spontaneous abortions according to work with a video display terminal (VDT) among the gainfully employed women. ( $95 \% \mathrm{Cl}=95 \%$ confidence interval of the adjusted rate ratio) in the case group of spontaneous abortions and in the base sample.

\begin{tabular}{|c|c|c|c|c|c|c|}
\hline \multirow{2}{*}{ VDT work } & \multicolumn{2}{|c|}{$\begin{array}{l}\text { Number of } \\
\text { pregnancies }\end{array}$} & \multirow{2}{*}{$\begin{array}{c}\text { Cases } \\
\text { in } \\
\text { base } \\
\text { sample }\end{array}$} & \multirow{2}{*}{$\begin{array}{l}\text { Crude } \\
\text { rate } \\
\text { ratio }\end{array}$} & \multirow{2}{*}{$\begin{array}{l}\text { Adjusted } \\
\text { rate } \\
\text { ratio }\end{array}$} & \multirow{2}{*}{$95 \% \mathrm{Cl}$} \\
\hline & $\begin{array}{l}\text { Case } \\
\text { group }\end{array}$ & $\begin{array}{l}\text { Base } \\
\text { sample }\end{array}$ & & & & \\
\hline None & 313 & 343 & 74 & . & . & - \\
\hline Any & 353 & 421 & 45 & 0.92 & 0.94 & $0.77-1.14$ \\
\hline \multicolumn{7}{|c|}{$\begin{array}{l}\text { Average number } \\
\text { of hours/week }\end{array}$} \\
\hline $\begin{array}{c}\text { None } \\
<1 \\
1-10 \\
11-20 \\
21-30 \\
31-40\end{array}$ & $\begin{array}{r}316 \\
24 \\
172 \\
77 \\
56 \\
21\end{array}$ & $\begin{array}{r}356 \\
32 \\
204 \\
83 \\
58 \\
31\end{array}$ & $\begin{array}{r}74 \\
7 \\
24 \\
4 \\
9 \\
1\end{array}$ & $\begin{array}{c}. \\
0.84 \\
0.95 \\
1.05 \\
1.09 \\
0.76\end{array}$ & $\begin{array}{c}. \\
0.86 \\
0.96 \\
1.05 \\
1.12 \\
0.78\end{array}$ & $\begin{array}{c}. \\
0.50-1.49 \\
0.76-1.25 \\
0.75-1.47 \\
0.76-1.65 \\
0.48-1.25\end{array}$ \\
\hline
\end{tabular}

a Adusted for maternal age with the Maentel-Haenszel stratified analysis (7).

b Detailed information on hours of VDT work/week was missing for 16 pregnancies. These pregnancies have been assigned a value of zero (none).

Table 5. Cross-tabulation of the women's and employers' statements on the women's work with a video display terminal (VDT) during pregnancy. ${ }^{a}$

\begin{tabular}{|c|c|c|c|c|c|c|c|c|c|c|}
\hline \multirow{3}{*}{$\begin{array}{l}\text { Woman's } \\
\text { statement } \\
\text { (hours of } \\
\text { VDT work/week) }\end{array}$} & \multicolumn{10}{|c|}{ Employer's statement (hours of VDT work/week) } \\
\hline & \multicolumn{2}{|c|}{$0-1$} & \multicolumn{2}{|c|}{$1-10$} & \multicolumn{2}{|c|}{$11-20$} & \multicolumn{2}{|c|}{$21-30$} & \multicolumn{2}{|c|}{$31-40$} \\
\hline & $\begin{array}{l}\text { Case } \\
\text { group }\end{array}$ & $\begin{array}{c}\text { Base } \\
\text { sample }\end{array}$ & $\begin{array}{l}\text { Case } \\
\text { group }\end{array}$ & $\begin{array}{c}\text { Base } \\
\text { sample }\end{array}$ & $\begin{array}{l}\text { Case } \\
\text { group }\end{array}$ & $\begin{array}{c}\text { Base } \\
\text { sample }\end{array}$ & $\begin{array}{l}\text { Case } \\
\text { group }\end{array}$ & $\begin{array}{c}\text { Base } \\
\text { sample }\end{array}$ & $\begin{array}{l}\text { Case } \\
\text { group }\end{array}$ & $\begin{array}{l}\text { Base } \\
\text { sample }\end{array}$ \\
\hline $0-1$ & - & 4 & - & 2 & - & - & - & - & - & - \\
\hline $1-10$ & 2 & 1 & 36 & 39 & 5 & 11 & - & 2 & - & 1 \\
\hline $11-20$ & - & - & 12 & 14 & 5 & 8 & 4 & 4 & 1 & 1 \\
\hline $21-30$ & - & - & 3 & - & 7 & 10 & 2 & 7 & 2 & - \\
\hline $31-40$ & - & - & 1 & - & 1 & 1 & - & 4 & 3 & 3 \\
\hline
\end{tabular}

a Case group $=$ case group of spontaneous abortions $(N=87)$ and base sample $(N=113)=9.2 \%$ random sample of the source population. The spontaneous abortions in the base sample have not been included. Test of agreement between the differences in the statements of the women and the employers in the case group and base sample by Mann-Whitney's U-rank sum test $(P=0.41)$.

Table 6. Estimation of selection bias. ${ }^{\text {a }}$ Among the total number of nonrespondents (pregnancies) in the source population a random sample was drawn. A telephone interview was made without the interviewer knowing the outcome of the pregnancy.

\begin{tabular}{|c|c|c|}
\hline VDT exposure & $\begin{array}{l}\text { Spontaneous } \\
\text { abortions }\end{array}$ & $\begin{array}{l}\text { Base sample } \\
\text { group }\end{array}$ \\
\hline \multicolumn{3}{|l|}{ Any } \\
\hline $\begin{array}{l}\text { Answers by mail } \\
\text { Answers by telephone } \\
\text { Expected } \\
\text { Sensitivity }\end{array}$ & $\begin{array}{c}371 \text { (e) } \\
9 \\
475.7(g) \\
a=0.780\end{array}$ & $\begin{array}{c}433 \\
23 \\
579.8 \\
b=0.747\end{array}$ \\
\hline \multicolumn{3}{|l|}{$\begin{array}{l}\text { None among the } \\
\text { employed }\end{array}$} \\
\hline $\begin{array}{l}\text { Answers by mail } \\
\text { Answers by telephone } \\
\text { Expected } \\
\text { Sensitivity }\end{array}$ & $\begin{array}{c}701 \\
44 \\
1212.9 \\
C=0.578\end{array}$ & $\begin{array}{c}856 \\
52 \\
1187.8 \\
d=0.721\end{array}$ \\
\hline \multicolumn{3}{|l|}{$\begin{array}{l}\text { None among } \\
\text { the unemployed }\end{array}$} \\
\hline $\begin{array}{l}\text { Answers by mail } \\
\text { Answers by telephone }\end{array}$ & $\begin{array}{r}231 \\
21\end{array}$ & $\begin{array}{r}318 \\
17\end{array}$ \\
\hline $\begin{array}{l}\text { Total answers by } \\
\text { telepthone }\end{array}$ & 74 (h) & 92 \\
\hline Nonrespondents & 861 (f) & 587 \\
\hline
\end{tabular}

time compared to no VDT use altogether. VDT use for $11-20$ and $21-30 \mathrm{~h} /$ week showed an insignificant relative risk of 1.05 and 1.12 , respectively, in a comparison with women with no VDT use during pregnancy.

Results similar to those in table 4 were obtained by means of a stratified analysis of the potentially confounding variables. Maternal age was the only variable that correlated significantly with the occurrence of spontaneous abortion. Ergonomic work load and job stress did not confound the results.

If the employers' reports of VDT use are correct (which is not necessarily the case), table 5 shows that women who reported VDT work for $1-10 \mathrm{~h} /$ week "underreported" their VDT use. Conversely, women who stated they worked $\geq 11 \mathrm{~h} /$ week with a VDT "overreported"' when their responses were compared with the information given by their employers. This tendency was even clearer in the base sample. Therefore selective recall was indicated which could bias the results towards high rate ratios. A test of agreement between the differences in the statements of the women and the employers in the case group and in the base 
sample by the rank sum test did not show any statistically significant disagreement.

Women who used a VDT and who had experienced a spontaneous abortion might be expected to be more willing to answer the questionnaires than women who gave birth to a normal child. This selection bias was estimated by the odds ratios of sensitivities in table 6 (9) (selection odds ratio $=1.30$ ).

\section{Discussion}

The 6541 pregnancies in the study represented 6212 women - 5894 women had had one pregnancy, 306 had had two, 9 had had three, and only 2 women had had four pregnancies in the follow-up period. The pregnancies were treated as independent events in the analysis although some women contributed with more than one pregnancy. The low average number of pregnancies $(\mathrm{N}=1.05)$ contributed by each woman was assumed to have a minor effect on the estimation and testing (10).

Recall bias has previously been mentioned as a possible explanation of findings of a positive association between VDT exposure and spontaneous abortion (1, 5). If recall bias was responsible for our negative findings, the women who experienced a spontaneous abortion must have underreported VDT exposure during pregnancy in comparison with the reporting of the women in the base sample group and/or the women in the base sample group must have overreported their VDT exposure in comparison with the women in the case group. In order to clarify this point, we compared the information given on VDT exposure by the women in the base sample, as well as those women who experienced a spontaneous abortion, with the information their employers gave on VDT use. As shown in table 5 , it is unlikely that recall bias could explain the finding of no association in this study.

The selection odds ratio was 1.30 . This value indicates that selection bias due to nonresponse produced a slight overestimation of the rate ratios.

The duration of pregnancy averaged nine months for those women who gave birth as compared with an average of three months for women who aborted. Thus the first group would have had a greater chance a priori for any VDT exposure and would, therefore, bias the comparison between spontaneous abortions and births in the direction of low risk ratios. Therefore, measurements of VDT exposure were expressed in terms of an average, that is, average exposure to work with a VDT during pregnancy. Such information is less dependent on the duration of pregnancy, and the study, in fact, supports this observation. When the groups of women who used a VDT to various extents during pregnancy were compared, no significant differences were found between the average VDT use when working and when not working. Detailed information on hours of VDT work at various stages of pregnancy was unfortunately not obtainable.

A woman who had previously experienced a spontaneous abortion might avoid VDT use if she planned to get pregnant again because of fear of the potential risk of adverse pregnancy outcome when using a VDT. Such behavior modification would lead to an underestimation between VDT use and spontaneous abortion. However, this study did not support the possibility that such behavior modification took place.

For ethical reasons, women who had had induced abortions were not contacted. There is, however, no reason to suspect an unequal distribution of induced abortions among the exposed and unexposed women. It should be mentioned that the relative risk, as calculated, is an unbiased estimator of the relative frequencies of spontaneous abortion of all recognized pregnancies under the nonnull hypothesis, but it is not so in the case of the null hypothesis (11). In conclusion, this study does not indicate an increased risk of medically verified spontaneous abortion for women using a VDT.

\section{Acknowledgments}

We wish to thank Professor J Olsen, Dr KO Larsen, and Ms L Helsborg for their scientific assistance. In addition the technical, administrative, and practical support of Ms B Waldstrøm, Ms LT Nielsen, Ms AC Dam, Ms AT Johansen, Mr SE Hermansen, and the Union of Commercial and Clerical Employees in Denmark and the performance of the telephone interviews by Ms $\mathrm{H}$ Brandt, Ms $\mathrm{H}$ Bräuner, Ms K Johansen, and Ms $\mathrm{H}$ Nicolaisen are gratefully acknowledged.

The study was financed by The Occupational Medical Research Fund in Aarhus, The Medical Research Fund, and The Health Fund.

\section{References}

1. Berqvist UOV. Video display terminals and health: a technical and medical appraisal of the state of the art. Scand J Work Environ Health 1984;10(suppl 2):87p.

2. Ericson A, Källén B. An epidemiologic study of video screens and pregnancy outcome: $I$. a register study. Am J Ind Med 1986;9:441-57.

3. Ericson A, Källén B. An epidemiologic study of video screens and pregnancy outcome: II. a case-control study. Am J Ind Med 1986;28:1226-31.

4. McDonald AD, Cherry NM, Delorme C, et al. VDU's and pregnancy: evidence from the Montreal survey. $\mathbf{J}$ Occup Med 1986;28:1226-31.

5. Goldhaber MK, Polen MR, Hiatt RA. The risk of miscarriage and birth defects among women who use visual display terminals during pregnancy. Am J Ind Med 1988;13:695-706.

6. Brandt LPA, Nielsen CV. Congenital malformations in children of women working with video display terminals. Scand J Work Environ Health 1990;16:329-33.

7. Miettinen OS. Theoretical epidemiology: principles of occurrence research medicine. New York, NY: John Wiley \& Sons, 1985. 
8. Greenland S. Adjustment of risk ratios in case-base studies (hybrid epidemiologic designs). Stat Med 1986; $5: 579-84$.

9. Kleinbaum DG, Kupper LL, Morgenstern H. Epidemiologic research: principles and quantitative methods. New York, NY: Lifetime Learning Publications, 1982; 194-219.

10. Butler WJ, Kalasinki LA. Statistical analysis of epidemi- ologic data of pregnancy outcomes. Environ Health Perspect $1989 ; 79: 223-7$.

11. Olsen J. Calculating risk ratios for spontaneous abortions: the problem of induced abortions. Int J Epidemiol 1984;3:347-9.

Received for publication: 5 May 1989 